TILTAI, 2016, 3, 77-98 ISSN 1392-3137 (Print), ISSN 2351-6569 (Online)

\title{
JAUNŲ BEDARBIŲ, TURINČIŲ AUKŠTĄJİ IŠSILAVINIMĄ, KARJEROS PROJEKTAVIMO VEIKSNIAI
}

\author{
Lilia Žukauskienė, Indrẻ Mickevičiūtė \\ Klaipédos universitetas, pramonès įmonè „Pelagia“ (Norvegija)
}

\begin{abstract}
Anotacija
Straipsnyje analizuojama jaunų bedarbių, turinčių aukštajji išsilavinimą, karjeros projektavimo problema. Jauno žmogaus integracija ị darbo rinką priklauso nuo daugelio individualių, socialinių, ekonominių veiksnių. Karjeros projektavimas yra vienas iš profesinę sėkmę lemiančių veiksnių. Aiškus siekiamų tikslų ir konkrečių uždavinių sau iškèlimas, optimaliai suplanuota ir lanksti jų igyvendinimo sistema padeda įgyti pranašumą konkurencinėje darbo rinkos aplinkoje. Straipsnyje pristatomi tyrimo su jaunais bedarbiais, turinčiais aukštaji išsilavinimą, rezultatai. Tyrimas atliktas remiantis pozityvizmo paradigma, taikant kiekybinio tyrimo metodą, geriausiai tinkanti tirti jaunų bedarbių, turinčių aukštaji išsilavinimą, požiūrị ị karjeros projektavimą, identifikuoti ši reiškinị lemiančius veiksnius. Nustatyta, kad jaunus bedarbius projektuoti savo karjerą skatina nuolat kintanti ekonominè situacija, statusas visuomeneje, nuolatinio mokymosi galimybès. Išsilavinusio jaunimo karjeros projektavimui teigiamos įtakos turi individualios savybès: atsakingumas, aktyvumas, smalsumas ir kt., taip pat gebejimai planuoti ir valdyti karjerą. Karjeros projektavimą apsunkina pasirinktai profesijai būtinų savybių stoka, savo jẻgų ir galimybių pervertinimas, praktinių profesijos žinių bei ịgūdžių trūkumas, darbo rinkos tendencijų nežinojimas.

PAGRINDINIAI ŽODŽIAI: nedarbas, jauni bedarbiai, aukštasis išsilavinimas, karjeros projektavimas, veiksniai.
\end{abstract}

\begin{abstract}
The paper presents an analysis of the issue of career design for young unemployed people with higher education. The integration of a young individual into the labour market depends on a number of individual, social, and economic factors. Career designing is one of the factors conducive to professional success. Clear goals and specific objectives set for oneself, as well as an optimally planned and flexible system of their implementation, contribute to one's competitiveness and advantages in the labour market. The paper introduces the results of the survey of young unemployed people with higher education. The survey was carried out, based on the paradigm of positivism and with the application of a quantitative research method, best suited for the investigation of the views of unemployed educated youth on the career design and the identification of the determinants of the phenomenon. As established, young unemployed people were encouraged to design their careers by the constantly changing economic situation, the social status, and the opportunities of lifelong learning. The career designing of educated young people was positively affected by their individual characteristics, such as responsibility, proactiveness, inquisitiveness, etc., as well as the ability to design and manage one's career. Career designing was impeded by the lack of personal characteristics required by the chosen profession, the overestimation of one's abilities, the absence of the practical professional knowledge and skills, and the ignorance of the trends of the labour market. KEY WORDS: unemployment, unemployed youth, higher education, career designing, factors.
\end{abstract}




\section{İvadas}

Jaunimo nedarbo problema aktuali visame pasaulyje. Pastaraji penkmeti daugelyje Europos šalių, tarp jų ir Lietuvoje, jaunimo nedarbo lygis buvo dvigubai didesnis už bendrą nedarbo lygị. Kas aštuntas Darbo biržoje registruotas žmogus buvo jauno amžiaus (Stanislava ir kt., 2011).

2015 metais situacija keitėsi. Darbo biržoje registruota 91 tūkst. jaunuolių iki 29 metų amžiaus, iš jų 14,6 tūkst. - absolventų. Palyginus su 2014 metais, jaunuolių kreipèsi 5,2 proc. mažiau. Jaunimas iki 29 metų sudare 34,2 proc. visų per metus registruotų bedarbių (2014 metais jų buvo 36,5 proc.). Europos Sajungos statistikos agentūros „Eurostat“ 2016 metų kovo mèn. duomenimis, jaunimo iki 25 metų nedarbo rodiklis Lietuvoje (16,3 proc.) buvo 4,1 proc. punkto mažesnis nei Europos Sajungos vidurkis (20,4 proc.) (Lietuvos darbo biržos duomenys, 2015).

Lietuvos Vyriausybe patvirtino Nacionalinę užimtumo didinimo 2014-2020 m. strategiją (2013), kurioje įvardijamos opiausios jaunimo nedarbo priežastys: viešasis ir privatusis sektoriai nesukuria pakankamai darbo vietų, darbo jègos kvalifikacija neatitinka paklausos, šalis susiduria su demografijos iššŭkiais, emigracija. Jaunimo nedarbo problemai spręsti būtina kompleksinè jaunimo nedarbo prevencijos sistema, kuri ịtrauktų visus suinteresuotus šio reiškinio dalyvius, būtų moksliškai pagrịsta.

Moksliniuose tyrimuose dėmesys skiriamas jaunimo užimtumo ir ịsitraukimo ị darbo rinką problemoms (Rudžinskienė, 2013; Andersen, 2012; Kvedaraitè ir kt., 2012; Stanislava ir kt., 2011; Gruževskis, kt., 2009; Okunevičiūtė-Neverauskienė ir kt., 2008; Gečienė, 2007; Švedaitė-Sakalauskė, 2012, kt.). Jaunų žmonių nedarbą lemiančios priežastys ir problemos atsiranda anksčiau nei žmogus patenka ị darbo biržą, o momentinès socialinès intervencijos problemų neišsprendžia. Nedarbas jaunus žmones skatina marginalizuotis, tapatintis su įvairiomis subkultūromis, didina jų socialinę atskirtị. Neigiamą poveiki jaunam žmogui turi ilgalaikis nedarbas (Beržinskienè, kt., 2010; Deprez, 2009 ir kt.).

Kaip pastebi B. Gruževskis ir kt. (2009), nors jauni žmonės nedarbo faktą išgyvena lengviau nei vyresni, dèl santykinai nedidelès darbinès patirties, nesusiformavusio prisirišimo prie darbo organizacijos, gebejjimo lengviau prisitaikyti prie besikeičiančiu aplinkybių, ilgalaikis nedarbas labai paveikia jaunimo pasitikẻjimą savo jègomis, skatina ir taip nedidelių profesinių bei socialinių ịgūdžių menkèjimą, apsunkina ateities perspektyvų planavimą.

Jaunimo sẻkmingai integracijai ị darbo rinką gali padèti laikinasis įdarbinimas (Švedaitè, 2012), nevyriausybinès organizacijos (Okunevičiūtè-Neverauskienè, kt., 2008). Efektyvesnị individo integravimąsi ị darbo rinką lemia turimas išsilavinimas, kvalifikacijos neturintys jaunuoliai bedarbiais tampa dažniau. B. Gruževskis 
ir kt. (2009) pažymi, kad išsilavinimo svarba gerokai išaugo prasidejjus sparčiam naujujų technologijų integravimui ị darbo procesus. Tačiau išsilavinę jaunuoliai susiduria ir su tokiomis problemomis kaip turimų profesinių žinių neatitiktis darbo rinkos poreikiams, darbdavių noras iškart turèti kvalifikuotą darbuotoją, darbo paieškos ịgūdžių, atkaklumo, užsispyrimo stoka ir kt.

Jaunų žmonių integracijos į darbo rinką veiksniams priskiriamas ir karjeros projektavimas. Karjera vertinama kaip profesinès veiklos ịprasminimo aspektas, profesinès veiklos potencialo, asmeninių savybių ir savimotyvacijos kompleksas (Hirschi ir kt., 2012). Moksliniuose tyrimuose (Baruch, 2006; Gerber, Wittekind, Grote, Staffelbach, 2009; AnsDe Vos Segers, 2013 ir kt.) išryškinamas karjeros sampratos universalumas, pritaikomumas bet kuriai rinkos ekonomikai, profesijai ar ekonominiam sektoriui, atskleisti sėkmingos karjeros plètros principai (Rosinaitè, 2010; Sinclair, 2009; Stanišauskienè, Večkienė, 2009). Karjeros projektavimas apima asmeninių interesų, gebèjimų, igūdžių ir darbo vertybių ịvertinimą, bendrų arba tikslingų sprendimų prièmimą - ką asmuo nori veikti gyvenime (ar bent pirmaisiais mokslų baigimo metais) (Gerber ir kt., 2009). Dinamiška karjeros projektavimo samprata leidžia teigti, kad karjeros projektavimas gali lemti žmogaus gyvenimo kokybę (Sinclair, 2009). Karjeros projektavimo svarbą savo tyrimuose pabrèžia ir daugelis Lietuvos mokslininkų (Petkevičiūtè, 2006, 2013; Rudžinskiené ir kt., 2012; Augiené, 2009; Stancikienè, 2009; Pukelis, 2008; Danilevičius, 2008, kt.).

N. Petkevičiūtè (2013) kaip pagrindinị karjeros vystymosi veiksnị ịvardija individo motyvacija, kurią lemia poreikių patenkinimas. Noras dirbti ir tobulèti yra pagrindinis karjeros plètros variklis. İtakos turi šios individualios paskatos: asmenybe ir jos išskirtiniai bruožai (Petkevičiūtè, 2006); intelektas, kuris rodo asmens gebejjimą mokytis, adaptuotis prie besikeičiančių sąlygų, kūrybiškumo laipsnị, socialinių santykių palaikymą ir kt. (intelektualiai nesubrendęs asmuo negali atsakingai ir racionaliai pasirinkti profesijos, negeba analizuoti tolesnès jos perspektyvos [Goleman, 2009]); asmens pašaukimas (Pociūtè, 2010); individo lytis (Augienė, 2009); internalizuotos vertybès, išsilavinimas (Stancikienè, 2009) ir kt.

Kita karjeros plètros veiksnių grupé dažniausia susijusi su ekonominiais ir socialiniais parametrais, atskleidžia asmens artimą aplinką ir šalies politikos tendencijas (Rudžinskienè, 2013; Petkevičiūtè, 2006 ir kt.).

Viena iš institucijų, kuri gali sudaryti sąlygas išsiugdyti karjeros projektavimo gebėjimus, yra aukštoji mokykla (Šedžiuvienė, kt., 2008). Čia gali būti teikiama pagalba, kaip plètoti karjerą, analizuoti darbo rinką ir jos poreikius, numatyti ilgalaikes prognozes. Aukštoji mokykla sudaro prielaidas igyti profesinės patirties, išsiugdyti savarankiško darbo ịgūdžius, mokytis projektuoti savo karjerą. Tačiau, kaip teigia V. Rosinaite (2009), profesinès mokyklos, kolegijos ir universitetai su- 
teikia absolventams profesinę kvalifikaciją, t. y. parengia būsimus darbo rinkos dalyvius darbui, profesijai, bet ne karjerai.

Asmeninių interesų, gebejjimų, ịgūdžių ir darbo vertybių visuma, individualūs bruožai (Gerber ir kt., 2009) padeda asmeniui ugdytis karjeros kompetenciją, gebẻjimą ją projektuoti (Rudžinskienė, kt., 2012). Karjeros projektavimui įtakos turi asmeninè, socialinè, mokymosi, įsidarbinimo kompetencijos. Asmeninė kompetencija padeda geriau save pažinti, motyvuoja nuolatiniam savianalizès procesui, objektyviam savęs vertinimui ir apmąstymui (Stanišauskienè, 2004, kt.). Socialinė kompetencija padeda bendrauti, bendradarbiauti ir veikti socialinèje erdvejje: argumentuotai diskutuoti, kalbètis, klausytis ir pažinti pašnekovą, vertinti jo mintis ir teiginius (Stanišauskienė, 2004). Pasak D. Karanauskienès ir kt. (2007), nuo identifikacijos su studijomis priklausys ir asmens akademinè sèkmè, ir įsidarbinimo galimybès bei konkurencingumas darbo rinkoje. Mokymosi kompetencija - gebejimas rinkti ir analizuoti informaciją, pritaikant ją veikloje, nuolat kintančioje aplinkoje (Stanišauskienė, 2004), spręsti iškylančias problemas, savikritiškai reflektuoti mokymąsi (Pukevičiūtè, 2007). Mokèjimas pasirinkti darbo vietą, pasirengti darbinei veiklai, įsidarbinti ir išlaikyti darbo vietą, remiantis ịgytomis žiniomis, ịnūdžiais, gebejjimais, vertybinèmis nuostatomis, padeda ugdytis įsidarbinimo kompetenciją (Čepas, 2008).

Europos visa gyvenimą trunkančio orientavimo politikos tinklo (angl. European Lifelong Guidance Policy Network) ekspertai akcentuoja tris svarbiausių kompetencijų blokus: savęs pažinimo ir ịtvirtinimo; galimybių pažinimo; gyvenimo (karjeros) tikslų kèlimo ir igyvendinimo (Europos visą gyvenimą trunkančio orientavimo politikos tinklo darbo ataskaita, 2008, p. 12).

Karjeros projektavimas yra sąmoningas individo pasirinkimas, skatinantis pažinti save, savo pašaukimą, gebejjimus, ieškoti ir gauti visapusišką informaciją apie profesiją, darbo rinką ir kt. (AnsDe Vos Segers, 2013). Tačiau suvokimas, kad periodiškai būtina skirti laiko savianalizei ir savo siekių bei tikslų atnaujinimui, dar gana retas.

Problema. Darbo rinkos reikalaujamų profesinių ir socialinių žinių, igūdžių, gebèjimų (panaudoti turimą patirtị, nuolat mokytis ir kt.) stoka trukdo asmeniui laimèti konkurencinèje kovoje. Asmuo, įgijęs aukštajį išsilavinimą, šiandien nėra garantuotas dèl darbo vietos. Nedarbas mažina pasitikẻjimą savo galimybėmis, silpnina motyvaciją dirbti ir siekti socialinès gerovès ateityje. Jaunų žmonių integracija ị darbo rinką priklauso nuo daugelio individualių, socialinių, ekonominių veiksnių. Karjeros projektavimas yra vienas iš profesinę sẻkmę lemiančių veiksnių. Aiškus siekiamų tikslų ir konkrečių uždavinių sau iškèlimas, optimaliai suplanuota bei lanksti jų ịgyvendinimo sistema padeda įgyti pranašumą konkurencinèje darbo rinkos aplinkoje. Jaunų bedarbių, turinčių aukštajj išsilavinimą, karjeros 
projektavimo problema aktuali, nes nuo įvairių su karjera susijusių sprendimų priklausys jaunuoliu gyvenimo kokybè.

Tyrimo tikslas: atskleisti jaunų bedarbių su aukštuoju išsilavinimu karjeros projektavimo veiksnius.

Hipotezè: aukštajj̨ išsilavinimą turinčius jaunus bedarbius projektuoti karjerą skatina tokios individualios savybės kaip atsakingumas, savarankiškumas, aktyvumas, smalsumas, gebejjimas planuoti ir valdyti karjerą, statuso visuomenejje siekis, nuolatinio mokymosi galimybės bei nuolat kintanti ekonominè situacija. Karjeros projektuoti neskatina pasirinktai profesijai reikiamų savybių stoka, savo jègų ir galimybių pervertinimas, praktinių profesijos žinių bei įgūdžių trūkumas, darbo rinkos tendencijų nežinojimas.

Tyrimo metodologija. Šiame tyrime remiamasi kiekybinio tyrimo strategija, kuri numato, kad žinios, kurios plètojamos per pozityvistinès filosofijos prizmę, pagrịstos objektyvios tikrovès stebejjimu ir matavimu. Jos turi būti patikrintos, kad galima būtų suprasti nagrinèjamą reiškinį. Kiekybiniame tyrime akcentuojamas kintamujų ryšys (Greswell, 2013, p. 36). Vykdant tyrimą atlikta ištisinė apklausa, kurios imtis buvo reprezentatyvi ne visos populiacijos atžvilgiu, o tik jaunų bedarbių, sutikusių dalyvauti apklausoje. Gauti duomenys analizuojami taikant statistinių duomenų apdorojimo programos SPSS (angl. Statistical Package for the Social Sciences) paketo 22.0 versiją. Skaičiuojami procentiniai duomenų pasiskirstymo dažniai, $\chi^{2}$ (chi kvadrato) kriterijus, Manno-Whitney'aus kriterijus (Vaitkevičius, Saudargienė, 2006), koreliacijos koeficientas remiantis Spirmenu. Koreliacijos koeficientai interpretuojami remiantis B. Bitinu (2006).

Tyrimas vyko 2015 metų vasario - balandžio mėnesiais. Tyrimui pasirinktas Klaipedos miestas, kuris yra vienas iš didžiujų Lietuvos miestų, Vakarų Lietuvos ekonomikos centras, darbo ir mokymosi atžvilgiu turintis savo specifiką. Tyrimo imtis. Klaipédos mieste 2015 metų vasario ménesị registruoti 705 asmenys nuo 21 iki 29 metų, igiję aukštaji išsilavinimą (Užimtumo ir nedarbo rodikliai, 2015).

Tyrimo imties dydis yra $n=255$ (paklaida $5 \%$ ). Kiekybinio tyrimo imtis sudaryta taikant netikimybinès kiekybinio tyrimo imties atrankos būdą - patogiaja atranka - apimantị tuos generalinès aibès vienetus, kurie yra lengvai prieinami tyrẻjui (Rupšienè, 2007, p. 13-19).

Klaipėdos miesto Darbo biržoje registruoti 21 iki 29 metu asmenys, turintys aukštaji išsilavinimą. Toks amžiaus tarpsnis pasirinktas atsižvelgiant ị tai, kad jaunuoliai jau yra baigę studijas ir iki 29 metų jie priskiriami jaunimo grupei, turi galimybę dalyvauti Lietuvos darbo biržos programose, kurios skirtos jaunimui. Ši socialinè grupe savita tuo, kad asmenys jau yra igiję auštajị išsilavinimą, turi kvalifikaciją, tačiau dèl ịvairių priežasčių (socialinių, ekonominių, demografinių) nèra integravęsi ị darbo rinką arba iš jos iškritę. 
Tyrimui atlikti pasirinktas anketinès apklausos metodas (Kardelis, 2007). Klausimynas parengtas, remiantis karjeros konstravimo teorijos (Savickas, 2005) nuostatomis, kad kiekvienas individas savo profesinę raidą ir karjeros plètrą projektuoja remiantis turimų individualių patirčių, sukauptų žinių ir gaunamos naujos informacijos visuma. Plètodamas savo profesinę veiklą, asmuo nuolat vertina ir interpretuoja turimą patirtị ir formuoja prasmę suteikiančias projekcijas. Remiamasi ir D. Super (1990) profesinès raidos teorija, kuri teigia, kad asmenys kiekviename karjeros pletros etape igyvendina tam tikrus uždavinius, pasitelkdami skirtingus vaidmenis. Karjeros modeliai nulemti socialinių ir ekonominių veiksnių, asmens protinių ir fizinių gebejjimų, asmeninių charakteristikų bei galimybių, kurias turi ir kuriomis gali pasinaudoti. Žinios apie karjeros esmę, jos dinamiką ir problemas, atsirandančias ịvairiose fazèse, yra būtina tikslingo karjeros projektavimo ir tolesnio valdymo sąlyga. Klausimyno patikimumui nustatyti matuotas Kronbacho alfa koeficientas (angl. Cronbach alpha). Nustatytas koeficientas - 0,864, kai maksimali galima reikšmė yra 1 (Vaitkevičius, Saudargienè, 2006, 160). Klausimyno patikimumo lygmuo aukštas.

Tyrimo dalyvių charakteristika. Tyrime dalyvavo 50,98 \% (130) moterų ir 49,02\% (125) vyrų. Aukštajji išsilavinimą turinčių jaunų bedarbių grupé lyties aspektu neišsiskyrè. Tyrimo dalyviai pagal amžiaus grupes pasiskirste maždaug po lygiai ị dvi grupes: 50,98 \% (130) 21-24 metų ir 49,02 \% (125) - 25-29 metų. Beveik pusè respondentu - 49,02 \% (125) yra ịgiję aukštaji universitetinị išsilavinimą (bakalauro laipsnis), kiek mažiau - 47,84 \% (122) igiję aukštaji neuniversitetini išsilavinimą ir tik labai maža dalis apklaustujų - 3,14 \% (8) yra baigę magistrantūros studijas (magistro laipsnis). Daugiausia jaunų bedarbių, dalyvavusių tyrime, yra baigę socialinius 53,73 \% (137) ir humanitarinius 20,00 \% (51) mokslus. Menų studijas baigę tyrimo dalyviai sudare $15,29 \%$, nedidelè dalis yra baigę technologijos (6,67 \%), fizinių (2,35\%), biomedicinos (1,96\%) mokslų studijas. Tikètina, kad socialinių mokslų populiarumas išlieka, o tai didina konkurenciją, todèl šios krypties programų absolventams sunkiau integruotis ị darbo rinką.

\section{Tyrimo rezultatai ir jų analizè}

Vykdant tyrimą daugelis (97,65 \% [249]) jaunų bedarbių, turinčių aukštajji išsilavinimą, baigę studijas dirbo ir tik labai maža dalis (2,35 \% [6]) nebuvo ịsidarbinę. Tyrimo dalyviai nurode priežastis, dèl kurių po studijų nedirbo: „nèštumas“, „,nepavyko rasti darbo“, „,nepavyko ịsidarbinti pagal specialybę“, „, norejjau pailsèti“. Daugumai aukštųju mokyklų absolventų pavyksta ịsidarbinti, bet tai, kad jie šiuo metu yra bedarbiai, leidžia manyti, jog jiems sunku išsaugoti darbo vietą. 
Respondentai nurodè, kodèl po studijų ịsidarbinę jie neteko darbo. Daugiau nei pusè $(53,75 \%$ [134]) išèjo iš darbo savo noru, kiti neteko darbo, nes pasibaigè terminuota darbo sutartis $(37,57 \%$ [93]). Kitos priežastys (patirties trūkumas, etatu mažinimas, įmonès bankrotas ar vadovų kaita) nebuvo nurodytos kaip esminès. Tikètina, kad darbas, kuri po studijų susirado absolventai, neatitiko jų lūkesčių (darbas buvo ne pagal igytą profesiją, nesudarytos sąlygos siekti karjeros, nepakankamas darbo užmokestis, nesilaikyta sutartyje numatytų sąlygų ir t. t.). Tai ir paskatino priimti savanorišką sprendimą atsisakyti darbo vietos.

Labiausiai išryškejjusios jaunimo nedarbo priežastys yra šios: nepakankamas darbo užmokestis - 77,23 \% (197), didelè konkurencija profesinejje srityje - 69,41 \% (177). Daugiau nei pusès tyrimo dalyvių teigimu, jų darbovieteje nesudarytos palankios darbo sąlygos - 65,10 \% (166). Daugiau nei puse respondentu - 58,04 \% (148) - pripažino, kad jie patys nepakankamai aktyviai ieško darbo. Daugiau nei trečdaliui - 34,51 \% (88) - trūksta darbo patirties ar profesinių ịgūdžių. Tik mažai respondentų daliai trūksta motyvacijos dirbti. Taigi jauni bedarbiai, turintys aukštaji išsilavinimą, labiau akcentuoja išorines savo nedarbo priežastis: mažą darbo užmokestį, didelę konkurenciją, darbo sąlygas, bet mažiau linkę pripažinti savo aktyvumo, patirties, profesinių igūdžiu svarbą ịsidarbinant.

Darbas jaunam žmogui suteikia saviraiškos galimybę, didina saugumo jausmą ir padeda kurti materialinę gerovę. Tyrimu nustatyta, koks jaunų bedarbių, turinčių aukštajị išsilavinimą, požiūris ị nedarbo pasekmes. Respondentų nuomone, labiausiai nedarbas neigiamai veikia psichinę sveikatą - 86,27 \% (220); slopina socialinị aktyvumą - 72,16 \% (184); mažina pasitikejimą savimi - 40,39 \% (103). Kiek daugiau nei pusė apklaustujų abejoja, ar nedarbas destruktyviai veikia santykius su artimaisiais - 61,57\% (157) ir turi neigiamą poveiki fizinei sveikatai - 47,18\% (114). Jaunų bedarbių požiūriu, nedarbas mažina psichinị ir socialinị aktyvumą, pasitikèjimą savo jègomis. Netekus darbo, nutrūksta socialiniai ryšiai, žmogus nesijaučia svarbus visuomenès narys, sunkiau patenkinami socialiniai poreikiai. Nedarbas menkina jauno žmogaus savivertę. Prastėja finansinė padètis, todèl asmuo priverstas riboti pomėgius, laisvalaikị. Didèja socialinẻ atskirtis.

Atlikus koreliacinę analizę, nustatyti statistiškai reikšmingi silpni neigiami ryšiai tarp respondentų kvalifikacinio laipsnio ir požymių, kad nedarbas neigiamai veikia fizinę sveikatą $(r=-0290 ; p<0,01)$; mažina pasitikèjimą savimi $(r=-0,232$; $p<0,01)$; destruktyviai veikia santykius su artimaisiais $(r=-0,2316 ; p<0,01)$. Taigi, kuo aukštesnis tyrimo dalyviu kvalifikacinis laipsnis, tuo mažiau nedarbas neigiamai veikia ju fizinę sveikata, mažina pasitikejima savimi, destruktyviai veikia santykius su artimaisiais. Respondentams, įgijusiems universitetinị išsilavinimą, nedarbo įtaka yra silpnesnè. 
Taikant Manno-Whitney'aus testą, nustatyti statistiškai reikšmingi skirtumai tarp vidurkio rangų lyginamose respondentų amžiaus grupèse. Lyginant jaunų bedarbių, turinčių aukštajj išsilavinimą, požiūrị ị nedarbą pagal amžiaus grupes (21-24 m. ir 25-29 m.) nustatyta, kad vyresni (25-29 m.) tyrimo dalyviai labiau nei jaunesni linkę manyti, kad nedarbas neigiamai veikia ju fizinę sveikata (miego, mitybos sutrikimai) $(p<0,05)$; slopina pasitikejima savimi $(p<0,01)$; destruktyviai veikia ju santykius su artimaisiais $(p<0,01)$. Jauni bedarbiai, turintys aukštaji išsilavinimą, vertindami nedarbo pasekmes, remiasi savo individualia patirtimi. Tikètina, kad jaunesni tyrimo dalyviai dar nebuvo ịsidarbinę arba neturejo darbo trumpesnị laiko tarpą, todèl nepatyrè (ar mažiau patyrè) neigiamo poveikio savo fizinei sveikatai, siekdami ịsidarbinti, neprarado pasitikèjimo savimi. Galbūt jaunesni bedarbiai dar nėra sukūrę savo šeimos, neturi vaikų, todėl nepajuto neigiamo nedarbo poveikio santykiams su artimaisiais.

Pusè respondentu - 53,33\% (136) Klaipėdos darbo biržoje registruoti nuo 1 mèn. iki 6 mèn., kiek mažiau - 38,04 \% (97) - nuo 6 mèn. iki 12 mèn., mažiau nei mėnesi $-6,67 \%$, neužsiregistravę $-1,96 \%$. Anot R. Rudžinskienès (2011), ilgalaikis bedarbis yra asmuo, ieškantis darbo metus ar ilgiau. Taigi nè vienas iš tyrimo dalyvių neturejo ilgalaikio bedarbio statuso. Galima daryti prielaidą, kad jauni ir išsilavinę žmonès, gyvenantys Klaipėdoje, ịsidarbina greičiau nei per metus. Taip jie išvengia ilgalaikès bedarbystès, nepatiria / mažiau patiria neigiamas nedarbo pasekmes.

D. Augienès (2009) teigimu, didelę reikšmę nedarbui turi šalies ir pasaulinès ekonomikos pokyčiai, išryškinantys tam tikrų profesijų poreikio išaugimą ar sumažejimą. Galima teigti, kad viena iš bedarbystès priežasčių gali būti nepaklausi profesija. Nustatyta, kaip jauni bedarbiai vertina savo profesiją. Trečdalis respondentu - 33,33\% (85) yra patenkinti savo profesija, net 65,88 \% (168) sieja su ja savo karjerą. Daugiau nei pusè respondentu - 53,73\% (137) - mano, kad turètu labiau tobulèti profesinejje srityje. Panaši dalis - 49,80 \% (127) - respondentų yra visiškai tikri, kad ieškos darbo tik pagal turimą profesiją.

Panašiai pasiskirstè tyrimo dalyviai, kurie dèl savo profesijos pasirinkimo abejoja - 36,47 \% (93) - ir yra nepatenkinti pasirinkta profesija - 26,27 \% (67). Pažymètina, kad net 78,43 \% (200) jaunų bedarbių, turinčių aukštaji išsilavinimą, neịsivaizduoja savęs dirbančių pagal pasirinktą profesiją po 10 metų. Kuo geriau žmogus pažista save ir darbo rinkos situaciją, tuo kryptingiau ir tikslingiau jis gali rinktis profesinę sritị. Pasirinkta profesinè sritis atskleidžia individo esmę ir prigimtinị pašaukimą. Asmeninių savybių ir profesijos pasirinkimo atitikimas didina pasitenkinimą profesija. 
Atlikus koreliacinę analizę, nustatyti statistikai reikšmingi silpni teigiami koreliaciniai ryšiai tarp respondentų kvalifikacinio laipsnio ir teiginių apie profesiją: savo karjera sieju su turima profesija $(r=0266 ; p<0,01)$; ketinu ir toliau gilintis žinias šioje sferoje ( $r=0,232 ; p<0,01)$. Taigi, kuo aukštesnis tyrimo dalyviu kvalifikacinis laipsnis, tuo dažniau jie sieja karjeros perspektyvas su igyta profesija. Taigi aukštesni išsilavinimą turintys absolventai (šiuo atveju tai universitetinis bakalauras ir magistras) dažniau sieja savo karjeros perspektyvas su igyta specialybe.

Taikant Manno-Whitney'aus testą, nustatyti statistiškai reikšmingi skirtumai tarp vidurkio rangų, lyginant duomenis pagal lytị ir amžių. Nustatyta, kad vyrai yra labiau patenkinti igyta profesija $(p<0,01)$ ir dažniau ieško darbo tik pagal turimą profesiją $(p<0,01)$ nei moterys. Tikètina, kad vyrai, priimdami profesinị sprendimą, geriau save pažino ir pasirinko profesiją ịsiklausydami ị savo vidinị pašaukimą, todèl yra labiau patenkinti savo profesiją ir dažniau nei moterys ieško darbo pagal igytą profesiją. Statistiškai reikšmingai skiriasi respondentų teiginio ketinu ir toliau gilinti žinias šioje srityje vertinimas pagal amžių $(p<0,01)$. Vyresnių tyrimų dalyvių (25-29 m.) teiginio vertinimo vidutiniai rangai yra aukštesni nei jaunesniujų (21-24), t. y. vyresni respondentai labiau nei jaunesni savo tolesnès karjeros planus sieja su ịgta profesija.

Tyrimo rezultatai atskleidè, kad trečdalis - 38,82 \% (99) - respondentų nenori keisti savo profesijos. Kiti tyrimo dalyviai nurode priežastis, dèl kurių norètų keisti pasirinktą profesiją arba persikvalifikuoti: noretų keisti, nes pasikeite darbo rinkos situacija ir turima profesija nebepaklausi - 24,31\% (62), neturi pasirinktai profesijai būtinų asmeninių savybių ir kompetencijų $-5,10 \%$ (13), surado įdomesnę veiklos sriti $-7,06 \%$ (18). Dalis respondentų norètų persikvalifikuoti, nes rinkosi profesiją nežinodami, ką galès dirbti, - 33,73\% (86), profesiją liepè rinktis tèvai - 23,92 \% (61). Dabartinè situacija darbo rinkoje vis dažniau verčia žmogu greičiau orientuotis, įvertinti kintančias sąlygas, dèl kuriu jis gali būti priverstas persikvalifikuoti arba net keisti savo profesiją. Tyrimo rezultatai, kad nemažai respondentų rinkosi profesiją, neturẻdami pakankamai informacijos apie jos specifiką ir perspektyvas, kai kuriems priimti profesinị sprendimą padejo tèvai, atskleidè, kad egzistuoja jaunų žmonių profesijos rinkimosi sambrandos problema. Tai ir gali lemti jaunų bedarbių, turinčių aukštajị išsilavinimą, poreikị vẻliau keisti profesiją arba persikvalifikuoti.

Nustatyti šie jaunų bedarbių šiuo metu svarbiausi darbo pasirinkimo prioritetai. Didžiajai daliai respondentų svarbiausia, kad darbe būtų sudarytos galimybės mokytis ir tobulèti - 68,24\% (174); siekti karjeros - 67,45 \% (172); darbe būtų darni aplinka ir darnus kolektyvas - 64,71 \% (165); darbas užtikrintų norimą užmokestị $-62,75 \%$ (172). Tokie prioritetai, kaip darbas pagal ịgytą profesiją, ir darbas, 
suteikiantis aukštą visuomenini statusą (prestižą), respondentams šiuo metu nėra svarbiausi. Tyrimo rezultatai rodo, kad jauniems bedarbiams, turintiems aukštaji išsilavinimą, svarbu ịsidarbinti ten, kur būtų darni aplinka ir darnus kolektyvas, sudarytos sąlygos mokytis, tobulèti profesinèje srityje, siekti karjeros, gauti norimą užmokestị už darbą.

Jaunų bedarbių, turinčių aukštąjį išsilavinimą, požiūris ị karjeros projektavimo veiksnius. Didžioji dalis respondentų pripažista, kad karjeros projektavimas ugdo gebejjimą planuoti, realizuoti ir valdyti asmeninę karjerą 80,39 \% (205). Nemažai respondentų mano, kad karjeros projektavimas užtikrina sėkmingą konkurenciją nuolat kintančioje darbo rinkoje - 65,49 \% (167), ir skatina pažinti save, savo pašaukimą bei gebèjimus, realiai save vertinti, nusistatyti veiklos prioritetus, juos derinti su mokymo(si) tikslais - 56,47 \% (144). Nedidelis respondentų skaičius karjeros projektavimą sieja su įsidarbinimo klausimais, savimonès plètote, gebejimu priimti sprendimus, profesinio tobulinimosi galimybių paieška.

Analizuojant gautus duomenis, taikytas chi kvadrato kriterijus. Nustatyta, kad respondentų nuomonè apie karjeros projektavimo svarbą tarp amžiaus grupių skiriasi ir skirtumai yra statistiškai reikšmingi. Jaunesni (21-24 m.) tyrimo dalyviai labiau nei vyresni (25-29 m.) linkę manyti, kad karjeros projektavimas skatina pažinti save, savo pašaukimą ir gebejimus, realiai save vertinti, nustatyti veiklos prioritetus, juos derinti su mokymo(si) tikslais $\left(\chi^{2}=22,058\right.$; df- $\left.1 ; p=0,000\right)$, taip pat skatina ieškoti informacijos apie profesines sritis, darbo rinką, tobulinimosi galimybes $\left(\chi^{2}=4,325\right.$; df- $\left.1 ; p=0,038\right)$.

Atlikus tyrimą atskleisti jaunų bedarbių, turinčiu aukštaji išsilavinimą, karjeros planai. Mažiau nei pusè tyrimo dalyvių planuoja vykti ị užsienį - 41,57 \% (106), trečdalis tobulinsis profesinèje srityje, nes nori būti gerais savo srities specialistais - 30,20 \% (77). Nedidelis skaičius jaunų bedarbių ketina tęsti mokymąsi, tobulintis arba kurti savo verslą. Respondentai, pasirinkę atsakymą „kita“, pažymėjo, kad sieks ịsidarbinti. Tyrimo rezultatai rodo, kad nemažai jaunų žmonių, igijusių aukštajị išsilavinimą Lietuvoje, neketina čia likti, ieškoti darbo ir dirbti. Tie, kuriems nepavyksta sẻkmingai integruotis ị darbo rinką Lietuvoje, karjeros planus sieja su galimybe dirbti užsienyje. Tikètina, kad kvalifikuoti specialistai vyksta ị užsienio šalis, siekdami ne tik didesnio uždarbio, bet ir socialinių garantijų bei savirealizacijos galimybių.

Tyrimu nustatyta, kokios asmeninès savybės labiausiai skatina jaunus bedarbius projektuoti savo karjerą (žr. 1 pav.). 


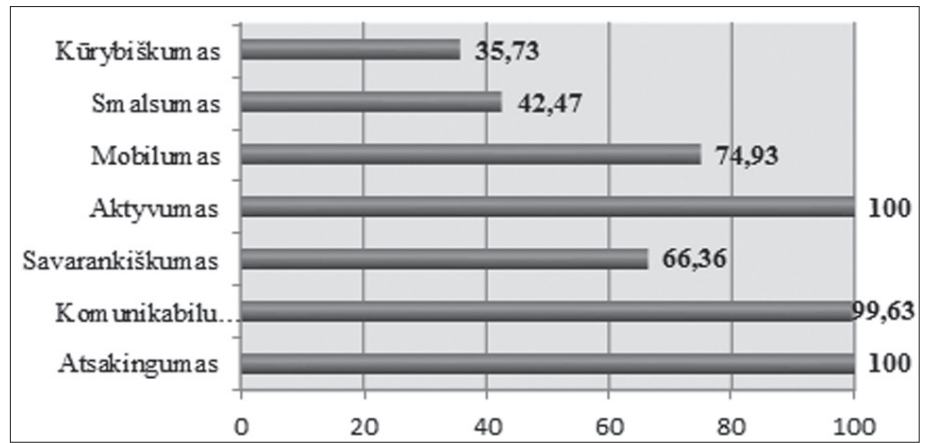

1 pav. Respondentų asmeninės savybès, skatinančios projektuoti karjerą

Visi respondentai sutinka, kad karjeros projektavimą skatina asmens aktyvumas $-100 \%$ (255) ir atsakingumas $100 \%$ (255). Taip pat beveik visi - 99,63\% (254) įsitikinę, kad komunikabilumas skatina siekti karjeros. Svarbios tyrimo dalyviams pasirodè savarankiškumo, smalsumo savybès. Vertinant šias asmenines savybes per karjeros projektavimo prizmę galima daryti prielaidą, kad aktyvumas yra svarbus ieškant darbo, atliekant visuomeninę veiklą, domintis inovacijomis bei saviugdos galimybėmis. Atsakingumas svarbus, nes sąžiningai vykdant savo pareigas galima pasiekti užsibrèžtų profesinių tikslų. Norit įsidarbinti labai svarbu gebėti įtikinamai kalbèti, prisistatyti, palaikyti pokalbị, užmegzti kontaktą, būti savarankišku ir smalsiu.

Tyrimu atskleisti jaunų bedarbių, turinčių aukštąị išsilavinimą, gebejjimai, skatinantys juos projektuoti karjerą (žr. 2 pav.).

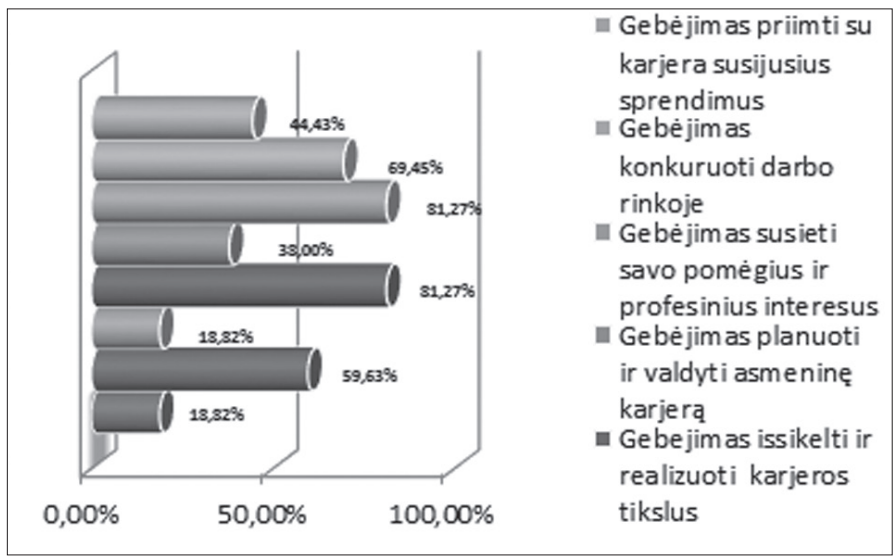

2 pav. Respondentų gebejjimai, skatinantys projektuoti karjerą 
Iš paveikslo matyti, kad respondentams svarbiausia gebėti: išsikelti ir realizuoti karjeros tikslus - 81,27\% (207); susieti savo pomėgius ir profesinius interesus - 81,27 \% (207); konkuruoti darbo rinkoje - 69,45 \% (177). Mažesné dalis respondentų mano, kad karjeros projektavimą skatina gebejjimas mąstyti strategiškai, įsiklausyti ị savo vidinị pašaukimą, priimti su karjera susijusius sprendimus. Taigi, projektuojant karjerą, tyrimo dalyviams svarbu išsikelti ir realizuoti karjeros tikslus, pomėgius derinti su profesija, būti konkurencingais darbo rinkoje.

Chi kvadrato kriterijaus duomenys rodo, kad respondentų nuomoné apie karjeros projektavimą skatinančius gebejjimus analizuojant pagal lytị skiriasi ir skirtumai yra statistiškai reikšmingi. Moterys labiau nei vyrai linkusios manyti, kad karjeros projektavimą skatina gebejjimas įsiklausyti ị savo vidini pašaukimą $\left(\chi^{2}=21,680 ; \mathrm{df}-1 ; p=0,000\right)$; prisitaikyti $\left(\chi^{2}=21,680 ; \mathrm{df}-1 ; p=0,000\right)$; planuoti ir valdyti asmeninę karjerą $\left(\chi^{2}=8,880\right.$; df- $\left.1 ; p=0,003\right)$; priimti su karjera susijusius sprendimus $\left(\chi^{2}=8,253\right.$; df- $\left.1 ; p=0,004\right)$. Chi kvadrato kriterijaus duomenys taip pat rodo, kad respondentų nuomonè apie karjeros projektavimą skatinančius gebėjimus, analizuojant pagal amžių, skiriasi ir tie skirtumai yra statistiškai reikšmingi. Vyresni (25-29 m.) tyrimo dalyviai labiau nei jaunesni (21-24 m.) linkę manyti, kad karjeros projektavimą skatina gebẻjimas ịsiklausyti ị savo vidini pašaukimą $\left(\chi^{2}=9,211\right.$; df-1; $\left.p=0,002\right)$; mąstyti strategiškai $\left(\chi^{2}=4,698\right.$; df- $\left.1 ; p=0,030\right)$; prisitaikyti $\left(\chi^{2}=9,211\right.$; df- $\left.1 ; p=0,002\right)$; susieti savo pomėgius ir profesinius interesus $\left(\chi^{2}=11,386 ; \mathrm{df}-1 ; p=0,001\right)$. Taigi vyresni tyrimo dalyviai labiau nei jaunesni supranta, kad bendros kompetencijos svarbios projektuojant karjerą.

Mokslinès literatūros analizė parodè, kad objektyvūs (išoriniai) veiksniai, dažniausiai siejami su socioekonomine aplinka, gali būti lengviau nuspèjami, tačiau sudètingiau kontroliuojami. Tyrimu atskleisti išoriniai veiksniai, kurie labiausiai skatina jaunus bedarbius, turinčius aukštaji išsilavinimą, projektuoti karjerą (3 pav.).

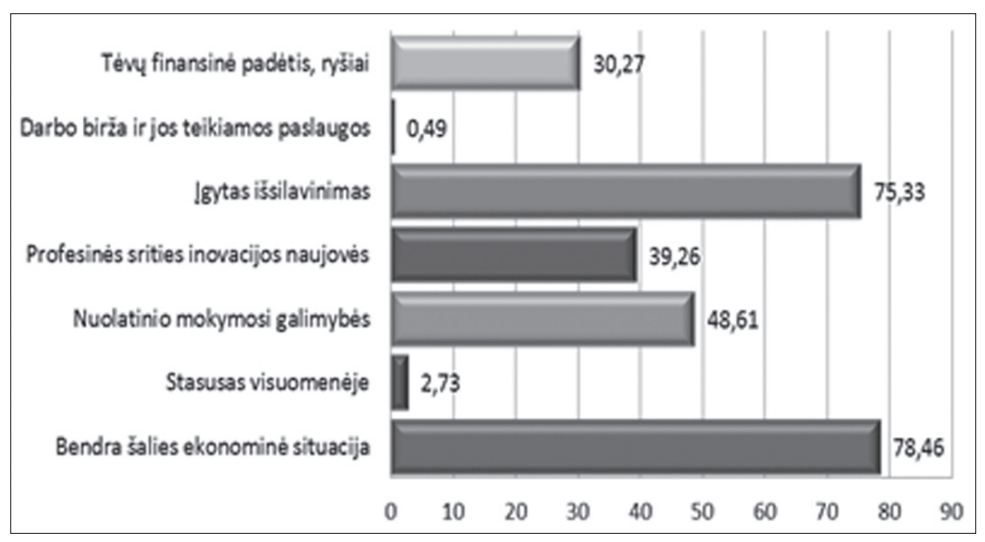

3 pav. Respondentų nuomonès apie išorinius veiksnius, skatinančius projektuoti karjerą 
Kaip svarbiausius išorinius veiksnius, lemiančius karjeros projektavimą, respondentai išskiria bendrą šalies ekonominę situaciją - 78,46 \% (200); igytą išsilavinimą - 75,33 \% (192). Beveik pusè respondentų mano, kad karjeros projektavimą skatina nuolatinio mokymosi galimybès - 48,61 \% (124). Mažiau nei trečdalị respondentų projektuoti karjerą skatina profesinès srities inovacijos ir naujovès, tèvų finansinè padètis. Nedidelè dalis respondentų nurodè, kad svarbūs veiksniai yra statusas visuomenėje ir darbo birža bei jos teikiamos paslaugos. Respondentai linkę manyti, kad bendra šalies ekonominè padètis turi įtakos jų karjeros projektavimui. Ekonominiai pokyčiai ir naujų informacinių bei komunikacinių technologijų skverbimasis ị daugelị gyvenimo sričių visam laikui panaikino galimybę tiksliai ir patikimai prognozuoti juos atitinkančias kvalifikacijas. Todèl galima teigti, kad respondentai supranta nuolatinio mokymosi svarbą kaip galimybę išlikti konkurencingam nuolat besikeičiančioje darbo rinkoje.

Tyrimu nustatyta, kas jauniems bedarbiams, turintiems aukštaji išsilavinimą, trukdo projektuoti karjerą (4 pav.).

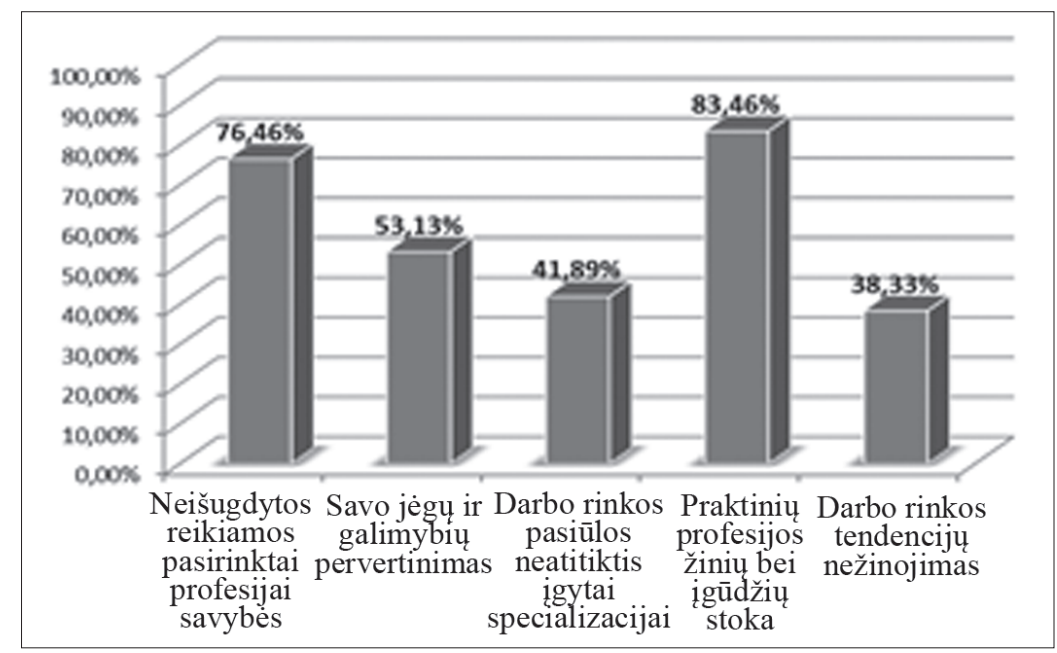

4 pav. Respondentų nuomonès dèl karjeros projektavimo trukdžių

Labiausiai karjeros projektavimui trūksta praktinių profesijos žinių bei įgūdžių - 83,46 \% (209); neišugdytos reikiamos pasirinkai profesijai savybès - 76,46 \% (187); savo jègų ir galimybių pervertinimas - 53,13 \% (136). Maždaug trečdalis respondentų nurodè, kad labiausiai trukdo darbo rinkos pasiūlos neatitikimas ịgytai specializacijai ir darbo rinkos tendencijų nežinojimas.

Tyrimo dalyviai, atsižvelgiant ị amžių ir ịgytą kvalifikacinị laipsnị, nurode skirtingus karjeros projektavimo trukdžius. Išsamesnei duomenų analizei naudotas chi kvadrato kriterijus. Gauti duomenys leidžia teigti, kad respondentų nuomonės apie 
karjeros projektavimo trukdžius, lyginant pagal lytị ir amžių, skiriasi ir tie skirtumai yra statistiškai reikšmingi. Moterys labiau nei vyrai mano, kad karjeros projektavimą apsunkina savo jègų ir galimybių pervertinimas $\left(\chi^{2}=8,582\right.$; df-1; $\left.p=0,003\right)$. Vyresni tyrimo dalyviai labiau nei jaunesni mano, kad neišugdytos pasirinktai profesijai būtinos savybès $\left(\chi^{2}=8,582\right.$; df-1; $\left.p=0,003\right)$, praktinių profesijos žinių bei igūdžių stoka $\left(\chi^{2}=9,678\right.$; df-1; $\left.p=0,002\right)$ trukdo projektuoti karjerą. Tačiau jaunesni tyrimo dalyviai labiau nei vyresni yra ịsitikinę, kad karjeros projektavimą apsunkina darbo rinkos tendencijų nežinojimas $\left(\chi^{2}=12,359\right.$; df- $\left.1 ; p=0,000\right)$.

Tyrimu atskleista, kad jauni bedarbiai savo karjeros projektavimo kompetenciją vertina kaip stiprią: 69,02 \% (176) tyrimo dalyvių mano, kad jų socialiniai gebejjimai (gebejjimas užmegzti ryšius, palaikyti pokalbị, diskutuoti ir pan.) yra stiprūs; beveik pusė $44,71 \%$ (114) respondentų teigia, kad turi parengę gerą gyvenimo aprašymą, todèl karjeros projektavimo kompetenciją vertina kaip stiprią. Jauni bedarbiai žino savo stipriąsias savybes - 49,02 \% (125), susipažinę su darbo rinkos tendencijomis - 46,67 \% (119), turi savo karjeros plètros planą - 43,92 \% (112). Šie respondentai savo karjeros projektavimo kompetenciją vertina vidutiniškai. Igūdžius darbo pokalbio metu vidutiniškai vertina mažiau nei pusė respondentų - 42,35 \% (108). Mažiau išryškejjo gebejjimai ịvertinti asmeninius privalumus ir trūkumus, taikyti ịvairius darbo paieškos būdus. Žmogus, išsiugdęs karjeros projektavimo kompetenciją, lengviau priima sprendimus bet kuriame karjeros etape, susidūręs su sunkumais geba pasirinkti tinkamą alternatyvą, lengviau prisitaiko prie ekonominių pokyčių. Karjeros projektavimo kompetencija apima asmenines savybes ir igūdžius, kurie būtini, siekiant veiksmingai siekti karjeros.

Atlikus koreliacinę analizę nustatyti statistiškai reikšmingi ryšiai tarp jaunų bedarbių, turinčių aukštaji išsilavinimą, karjeros projektavimo kompetencijos vertinimo ir jų amžiaus (žr. 5 pav.).

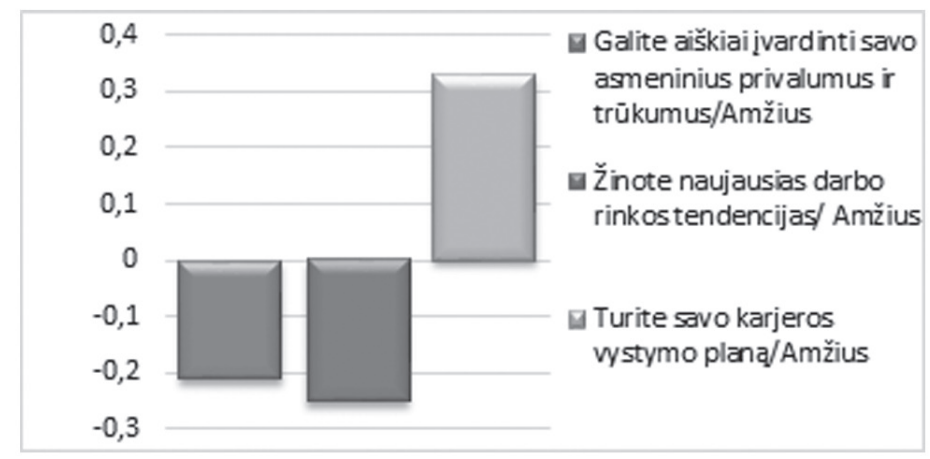

5 pav. Respondentų karjeros projektavimo kompetencijos vertinimo ir amžiaus koreliacija 
Nustatyti statistikai reikšmingi silpni neigiami koreliaciniai ryšiai tarp respondentų amžiaus ir jų savo asmeninių privalumų bei trūkumų vertinimo $(r=-0,206$; $p<0,01)$, jų žinių apie naujausias darbo rinkos tendencijas $(r=-0,261 ; p<0,01)$, teigiamas ryšys tarp amžiaus ir turimo savo karjeros pletros plano $(r=0,339$; $p<0,01)$. Kuo vyresni tyrimo dalyviai, tuo žemiau jie vertina savo gebejjimą aiškiai ìvardyti asmeninius privalumus bei trūkumus, taip pat ir darbo rinkos tendencijų pažinimą. Tačiau, kuo vyresnis tyrimo dalyvis, tuo labiau jis rūpinasi savo karjeros plètros planu.

Atlikus koreliacinę analizę nustatyti statistiškai reikšmingi ryšiai tarp jaunų bedarbių, turinčių aukštaji išsilavinimą, karjeros projektavimo kompetencijos vertinimo ir jų igyto kvalifikacinio laipsnio (žr. 6 pav.).

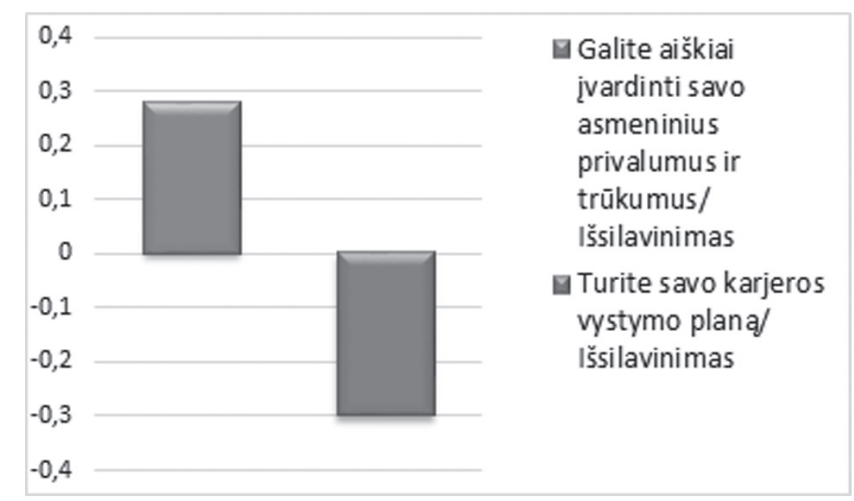

6 pav. Respondentų karjeros projektavimo kompetencijos vertinimo ir kvalifikacijos laipsnio koreliacija

Nustatytas statistiškai reikšmingas silpnas teigiamas koreliacinis ryšys $(r=0,283 p<0.01)$ tarp respondentu gebejimo ịvardyti savo asmeninius privalumus ir trūkumus bei kvalifikacinio laipsnio. Kuo aukštesnis tyrimo dalyvių kvalifikacinis laipsnis, tuo projektuodami karjerą jie labiau geba įvardyti savo asmeninius privalumus ir trūkumus.

Be to, nustatytas silpnas neigiamas statistiškai reikšmingas ryšys $(r=-0,296$, $p<0.01)$ tarp respondentų kvalifikacinio laipsnio ir teiginio apie karjeros plètros planą. Kuo aukštesnis tyrimo dalyvių kvalifikacinis laipsnis, tuo mažiau jie linkę sudarinèti savo karjeros plètros planą. Taigi universitetinį bakalauro ir magistro laipsnị turintys absolventai mano geriau save pažistantys ir labiau gebantys įsivertinti savo privalumus bei trūkumus nei turintieji neuniversitetinį aukštaji išsilavinimą. 


\section{Tyrimo rezultatų apibendrinimas ir išvados}

Atlikus jaunų bedarbių, turinčių aukštajj išsilavinimą, karjeros projektavimo veiksnių tyrimą nustatyta, kad jauni žmonès iš darbo neretai pasitraukia savo noru, o naujam darbui kelia didelius reikalavimus: akcentuoja didesnị darbo užmokestị, tikisi, kad darbovietė sudarys galimybes siekti karjeros ir visybiškai tobulèti, dirbti darnioje aplinkoje. Tai patvirtina B. Gruževskis, L. Okunevičiūtè-Neverauskienė (2009). Jų teigimu, integruodamiesi ị darbo rinką jauni žmonès patiria neatitikimą tarp turimų profesinių žinių ir darbo rinkos poreikių. Nedarbas menkina jaunų bedarbių savivertę, slopina socialinį aktyvumą, neigiamai veikia psichinę ir fizinę sveikatą. Tai patvirtina užsienio mokslininkès E. Deprez (2009) tyrimą, kuriuo įrodyta, kad nedarbas neigiamai veikia žmonių gyvenimo kokybę, netekus darbo gyvenime atsiranda daug įtampos, nerimo, streso, sutrikimų, prastēja santykiai su artimaisiais.

Nustatyta, kad kuo aukštesnis tyrimo dalyvių kvalifikacinis laipsnis (baigę universitetus), tuo silpnesnę neigiamą įtaką jiems daro nedarbas. Tai iš dalies patvirtina R. Rudžinskienès (2013) tyrimo išvadas, kad išsilavinimas yra lemiamas veiksnys, vertinant asmens atsparumą nedarbo keliamai neigiamai psichologinei būsenai. Labiau išsilavinę žmonès intensyviau kovoja su pasitikejjimo savimi mažèjimu, lengvai nepasiduoda užklupusioms problemoms.

Karjeros projektavimo svarbą pagrindžia ir ją projektuoti skatina globalizacijos iššūkiai, nuolat kintanti socialinė bei ekonominè aplinka, technologinis progresas, noras neatsilikti nuo naujovių. Jauniems bedarbiams karjeros projektavimas padeda vertinti darbo rinkos tendencijas, įžvelgti prognozuojamus pokyčius, adaptuoti savo profesinę karjerą, koreguoti profesinès kvalifikacijos tobulinimosi poreikius. Jauni bedarbiai, turintys aukštaj̨̣ išsilavinimą, karjeros projektavimą supranta kaip visą gyvenimą trunkantị asmeninį ir profesinį tobulèjimą, pripažįsta jo svarbą savirealizacijai, atliekamo darbo kokybei, gyvenimo ịprasminimui. Jų požiūris ị karjeros projektavimo svarbą skiriasi atsižvelgiant ị amžių: jaunesni bedarbiai labiau nei vyresni mano, kad karjeros projektavimas skatina pažinti save, savo pašaukimą ir gebejimus, realiai vertinti save, nustatyti veiklos prioritetus, juos derinti su mokymo(si) tikslais. Tyrimo rezultatai patvirtina J. AnsDe Vos Segers (2013) teigini apie karjeros projektavimą kaip neišvengiamą procesą, siekiant pirmauti darbo rinkos konkurencinejje aplinkoje, ir V. Sinclair (2009) įžvalgas apie karjeros projektavimo ịtaką žmogaus gyvenimo kokybei.

Tyrimu atsiskleista, kad tokios asmeninès savybès kaip aktyvumas, atsakingumas, komunikabilumas, savarankiškumas, smalsumas yra veiksniai, skatinantys jaunus bedarbius projektuoti savo karjerą. Kaip karjeros projektavimo veiksnius tyrimo dalyviai išskyre gebejjimą išsikelti ir realizuoti karjeros tikslus, derinti pro- 
fesinius interesus su pomėgiais, konkuruoti darbo rinkoje. Jauni bedarbiai, turintys aukštaji išsilavinimą, nebijo rizikuoti, mokytis, yra imlūs naujovèms, geba naudotis šiuolaikinėmis technologijomis, ieško būdų, kaip save pristatyti darbdaviui, igyti didesnị pasitikejjimą. Šie tyrimo rezultatai patvirtino R. Rudžinskienės (2013) teigini, kad asmeninės žmogaus savybès, vertybinès nuostatos, igytos kompetencijos, turimos darbui būtinos žinios ir gebėjimai yra sẻkmingos integracijos ị darbo rinką paskatos. Taip pat patvirtino M. Gerber ir kt. (2009) mintị, kad asmeniniai interesai, gebejjimai, igūdžių ir darbo vertybių ịvertinimas, bendrų arba tikslingų sprendimų prièmimas skatina projektuoti karjerą (bent jau pirmaisiais mokslų baigimo metais), N. Petkevičiūtès (2013) įžvalgą apie asmens aktyvumo ir mobilumo ryši su asmenine karjera. Tyrimo rezultatai parode, kad kuo aukštesnis tyrimo dalyvių kvalifikacinis laipsnis, tuo mažiau jie linkę sudarinèti savo karjeros plètros planą. Universitetinị bakalauro ir magistro laipsnị turintys absolventai mano geriau save pažįstantys ir labiau gebantys ịsivertinti savo privalumus bei trūkumus nei turintieji neuniversitetini aukštaji išsilavinimą. Tai atskleidžia jų mokymosi kompetenciją, gebejimą rinkti ir analizuoti informaciją, pritaikyti ją veikloje, nuolat kintančioje aplinkoje (Stanišauskienè, 2004), spręsti iškylančias problemas, savikritiškai reflektuoti (Pukevičiūtè, 2007). Tyrimo rezultatai apie jaunų bedarbių paminètus gebejjimus megzti ryšius, palaikyti pokalbị, diskutuoti ir pan., parengtą gerą gyvenimo aprašymą patvirtina P. Čepo (2008) mintị apie ịsidarbinimo kompetencijos reikšmingumą. Aiškus siekiamų tikslų ir konkrečių uždavinių sau kèlimas, suplanuota jų igyvendinimo sistema padeda ịgti pranašumą konkurencinèje darbo rinkos aplinkoje. Nuolat besikeičiančioje darbo rinkoje jauniems bedarbiams svarbūs ir bendrieji, ir profesiniai gebejimai.

Jaunų bedarbių, turinčių aukštaji išsilavinimą, karjeros projektavimą labiausiai skatina socialiniai veiksniai, bendra šalies ekonominė situacija, jų iggytas išsilavinimas, nuolatinio mokymosi galimybès. Tyrimo rezultatai patvirtino kitu autorių tyrimus apie karjeros plètros veiksnius, kurie susiję su ekonominiais ir socialiniais parametrais (Rudžinskienè, 2013; Petkevičiūtè, 2006 ir kt.). Tyrimo rezultatai atskleidè, kad didžiausi karjeros projektavimo trukdžiai jauniems bedarbiams yra praktinių profesijos žinių trūkumas, neišsiugdytos profesijai būtinos savybės, savo jègų ir galimybių pervertinimas, darbo rinkos pasiūlos ir ịgytos specializacijos neatitikimas ir darbo rinkos tendencijų nežinojimas. Jie patvirtina B. Gruževskio ir kt. (2009) išvadą, kad išsilavinusiems jaunuoliams trūksta darbo paieškos igūdžių, atkaklumo, užsispyrimo ir kt. savybių, jų turimos profesinės žinios ne visada atitinka darbo rinkos poreikius. Iš dalies šie tyrimo rezultatai patvirtina ir V. Rosinaitės (2008) teigini, kad profesinės mokyklos, kolegijos ir universitetai parengia būsimus darbo rinkos dalyvius darbui, profesijai, bet ne karjerai. 
Tyrimo hipotezė pasitvirtino. Išsilavinusio jaunimo karjeros projektavimą teigiamai veikia šios individualios savybès: atsakingumas, savarankiškumas, aktyvumas, smalsumas, gebejjimai planuoti ir valdyti karjerą, priimti su karjera susijusius sprendimus. Projektuoti karjerą skatina atitinkamo statuso visuomenèje siekis, nuolat kintanti ekonominė situacija, nuolatinio mokymosi galimybės. Jaunų bedarbių, turinčių aukštaj̨̣ išsilavinimą, karjeros projektavimą apsunkina pasirinktai profesijai būtinų savybių stoka, savo jẻgų ir galimybių pervertinimas, praktinių profesijos žinių bei ịgūdžių trūkumas, darbo rinkos tendencijų nežinojimas.

Gauta 20161111

Pasirašyta spaudai 20161203

\section{Literatūra}

Andersen, D. (2012). Europos ekonomikos ir socialiniu reikalų komiteto nuomoné dèl Jaunimo užimtumo, profesinių kvalifikacijų ir judumo (nuomone savo iniciatyva). Europos Sajungos oficialusis leidinys.

AnsDe Vos Segers, J. (2013). Self-directed Career Attitude and Retirement in Tentuos. Career Development International, Vol. 18, p. 155-172.

Augienè, D. (2009). Karjera: nuo profesijos iki pasirinkimo veiklos organizacijoje. Šiaulių universiteto leidykla.

Baruch, Y. (2006). Career development in organizations and beyond: Balancing traditional and contemporary viewpoints. Human resource Management Review, No. 16, p. 125-138. Prieiga internete: <https://www. google.lt/\#q=Baruch+Y.+2006.+Career+development+in+organizations+and+beyond $\% 3 \mathrm{~A}+$ Balancing + tra ditional+and + contemporary+viewpoints $+\% 2 \mathrm{~F} \% 2 \mathrm{~F}+$ Human + resource + Management + Review $\% 2 \mathrm{C}+$ No. +1 $6 \% 2 \mathrm{C}+$ p. $+125 \% \mathrm{E} 2 \% 80 \% 93138>$ [žiūrèta 2015-03-12].

Beržinskienè, D., Būdvytytė-Gudienè, A. (2010). Ilgalaikio nedarbo dinamika ekonominio nuosmukio sąlygomis. Ekonomika ir vadyba: aktualijos ir perspektyvos, Nr. 1, p. 15-24.

Bitinas, B. (2006). Edukologinis tyrimas: sistema ir procesas. Vilnius: Kronta.

Čepas, P. (2008). Isidarbinimo kompetencijos ugdymo modeliavimas profesiniame rengime. Disertacija. Vytauto Didžiojo universitetas.

Danilevičius, E. (2008). Karjeros projektavimo ir karjeros planavimo ugdymo edukologinès prielaidos. Pedagogika, Nr. 92, p. 110-115.

Deprez, Esme, E. (2009). A new Rutgers study reveals the impact of unemployment on the individual, including depression, anxiety, and strained relationships. Business week online. Prieiga internete: http://web. ebscohost.com/bsi/detail?vid=49\&hid=13\&sid=cea75fbf-d927-46ac-9352-c835879fd0ec\%40sessionmgr1 1\&bdata=JnNpdGU9YnNpLWxpdmU\%3d\#db=bth\&AN=44126742 [žiūrèta 2014-04-22].

Europos visa gyvenima trunkančio orientavimo politikos tinklo darbo ataskaita 2008-2010 m. Prieiga internete: $<$ http://www.elgpn.eu/publications/browsebylanguage/lithuanian/LT_ELGPN_2008_10_Short_Report. pdf/> [žiūrèta 2015-01-17].

Gečienè, I. (2007). Pažeidžiamo jaunimo integracijos j darbo rinka sunkumai: problemos ir mastai. Socialiai pažeidžiamo jaunimo integracijos $i$ darbo rinka prielaidos Lietuvoje. Vilnius: Viešosios politikos ir vadybos institutas.

Gerber, M., Wittekind, A., Grote, G., Staffelbach, B. (2009). Exploring types of career orientation: A latent class analysis approach. Journal of Vocational Behavior, Vol. 75 (3), p. 303-318.

Goleman, D. (2009). Emocinis intelektas. Vilnius: Presvika.

Creswell, J. (2013). Research Design / Qualitative, Quantitative, and Mixed Methods Approaches. Fourth Edition. Thousand Oaks: SAGE Publications.

Gruževskis, B., Okunevičiūtè-Neverauskienė, L. (2009). Jaunimo integracijos ị darbo rinka problemos. Vilnius: Vilniaus Gedimino technikos universitetas.

Hirschi, A., Hermann, A. (2012). Vocational Identity Achievement as a Mediator of Presence of Calling and Life Satisfaction. Journal of Career Assessment, Vol. 20(3), p. 309-321. 
Karanauskienė, D., Kardelienė, L., Kardelis, K. (2007). Būsimojo specialisto identifikacija su studento vaidmeniu kaip profesinès karjeros sąlyga. Ugdymas. Küno kultūra. Sportas, Nr. 1(64), p. 16-21.

Kvedaraite, N., Repeckiene, A., Glinskiene, R., Zvireliene, R. (2012). Youth Employment and Measures that Facilitate Inclusion into the Labour Matket. Socialiniai tyrimai, Nr. 4, p. 82-90.

Lietuvos darbo biržos duomenys. (2015). Prieiga internete: http://www.ldb.lt/informacija/veikla/documents/ ataskaitos/lietuvos\%20darbo\%20bir\%C5\%BEos\%20veikla\%202015\%20metais.pdf [žiūrèta 2016-10-14].

Nacionaline užimtumo didinimo strategija 2014-2020 metams. (2013). Prieiga internete: http://www.socmin.lt/lt/ veikla/koncepcijos-strategijos.html [žiūrèta 2014-10-17].

Okunevičiūtè-Neverauskienè, L., Moskvina, J. (2008). Socialiai pažeidžiamo jaunimo problemos integracijos i darbo rinką kontekste. Filosofija. Sociologija, Nr. 19 (2), p. 41-45.

Okunevičiūtè-Neverauskienè, L., Šlekienè, K. (2008). Nevyriausybinių organizacijų įtaka jaunimo integracijai ị darbo rinką. Filosofija. Sociologija, Nr. 19, p. 10-21.

Petkevičiūtè, N. (2013). Karjeros valdymas: organizacine perspektyva. Vilnius: VDU 1-kla.

Petkevičiūtè, N. (2006). Karjeros valdymas. Asmeninè / individualioji / perspektyva. Kaunas: VDU leidykla.

Pociūtè, B. (2010). Leono Jovaišos indèlis ì profesinio orientavimo tyrimus ir praktiką. Acta Paedagogica Vilninsis, Nr. 25, p. 43-56. Prieiga internete: http://www.euroguidance.lt/uploads/files/Pociute_B_L_ Jovaisos_indelis_i_PO.pdf [žiūrèta 2015-01-17].

Pukelis, K. (2008). Karjeros projektavimo metodologija. Kaunas: VDU leidykla.

Pukevičiūtè, V. J. (2007). Mokymosi mokytis kompetencijos ugdymo aspektai. Acta Paedagogica Vilnensia. Mokslo darbai, Nr. 19, p. 17-25.

Rosinaitè, V. (2010). Karjeros sampratos konstravimas Lietuvoje. Daktaro disertacija. Socialiniai mokslai. Sociologija. Vilnius: Vilniaus universitetas.

Rosinaitė, V. (2008). Lietuvos aukštųjų mokyklų studentų career development kompetencijos: subjektyvus jų įsisavinimo lygio ir ugdymo poreikio ịvertinimas. Filosofija. Sociologija, T. 19, Nr. 4. Prieiga internete: http://www.lvb.lt/primo_library/libweb/action/dlDisplay.do?vid=LDB\&docId=TLITLIJ.04 2008 136716 3081485\&fromSitemap=1\&afterPDS=true [žiūrèta 2014-09-03].

Rudžinskienė, R. (2013). Jaunų ilgalaikių bedarbių integracijos ị darbo rinką ypatumai. Socialine teorija, empirija, politika ir praktika, Nr. 7, p. 24-37.

Rudžinskienè, R., Paulauskaitė, L. (2012). Karjeros projektavimo gebėjimų ugdymas. Studijos šiuolaikinëje visuomeneje, Nr. 3, p. 203-213.

Rupšienè, L. (2007). Kiekybinio tyrimo imties dydis. Kokybinio tyrimo duomenu rinkimo metodologija. Klaipėda: KU 1-kla.

Savickas, M. L. (2005). The theory and practice of career construction in Career development and counseling. S. D. Brown, R. W. Lent (eds.). New Jersey: John Wiley \& Sons.

Sinclair, V. (2009). How to maximize the chances of career satisfaction and career success Counselling at Work, September. Prieiga internete: http://www.mentalhealthacademy.com.au/journal_archive/bacpwp0917.pdf) [žiūrèta 2014-06-17].

Stancikienè, A. (2009). Teoriniai profesinès karjeros valdymo aspektai. Viešoji politika ir administravimas, Nr. 29, p. 107-113. Prieiga internete: http://www.euroguidance.lt/uploads/files/straipsniai/A_Stancikiene_ Profesine\%20karjera.pdf [žiūrèta 2014-09-17].

Stanislava, I., Patašienė, I., Bieliūnaitė, E., Stanionytė, E., Zaburaitė, D. (2011). Kaimo jaunimo nedarbas. Kaimo žmonių kryptys žinių visuomenèje, Nr. 2, p. 46-60.

Stanišauskienė, V., Večkienė, N. (2009). Karjeros samprata: mokslinio požiūrio kaita ir jos refleksijos Lietuvai problema. Socialiniai mokslai, Nr. 2 (19), p. 23-31.

Stanišauskienè, V. (2004). Rengimosi karjerai proceso socioedukaciniai pagrindai. Kaunas: Technologija.

Super, D. (1990). Life Career Roles: Self-Realization in Workand Leisure. San Francisco, CA: Jossey-Bass.

Šedžiuvienė, N., Urbonienė, L. (2008). Profesinis orientavimas aukštojoje mokykloje: veiklos principai ir kryptys. Vilnius: Vilniaus pedagoginio universiteto leidykla.

Švedaitè, E. (2012). Laikinasis įdarbinimas kaip jaunimo nedarbo lygị Lietuvoje ir Europos Sajungoje mažinanti darbo alternatyva. Profesinis rengimas: tyrimai ir realijos, Nr. 10, p. 107-115.

Užimtumo ir nedarbo rodikliai. (2015). Socialinès apsaugos ir darbo ministerijos duomenys. Prieiga internete: http://www.socmin.lt/lt/darbo-rinka-uzimtumas/uzimtumo-ir-darbo-z6qc/uzimtumas-ir-nedarbas.html [žiūrèta 2015-04-23].

Vaitkevičius, R., Saudargienė, A. (2006). Statistika su SPSS psichologiniuose tyrimuose. Kaunas: VDU leidykla. 


\section{CAREER DESIGN FACTORS FOR YOUNG UNEMPLOYED PEOPLE WITH HIGHER EDUCATION}

\section{Lilia Žukauskienė, Indrẻ Mickevičiūtė}

\section{Summary}

Unemployment is one of the pressing problems of the contemporary economy. Upon the acquisition of higher education, an individual can no longer be sure of getting a job. The current situation requires both a good understanding of the labour market needs and the trends of their changes and also the ability of planning, implementation, and management of one's own personal career.

The integration of a young individual into the labour market depends on a number of individual, social, and economic factors. Career designing is one of the factors conducive to professional success. Clear goals and specific objectives set for oneself, as well as an optimally planned and flexible system of their implementation, contribute to one's competitiveness and advantages in the labour market. The issue of career design for young unemployed people with higher education is topical, as the quality of young people's further life will depend on different career-related solutions.

The paper presents the results of a survey, carried out in 2015, which discloses the views of young unemployed people with higher education on the career design factors. The case of the city of Klaipeda was analysed. Klaipeda is one of the major cities of Lithuania and an economic centre of the region of Western Lithuanian, specific in terms of employment and studies. The participants of the survey were 255 individuals registered with the Job Centre of the city of Klaipeda, aged 25 to 29 , all with higher education. Those included people who have acquired higher University education (the bachelor's degree), higher non-university education, and a small number of people with the master's degree. The majority of the unemployed educated youth completed studies in the area of humanities and social sciences. An insignificant part of the survey participants graduated from study programmes in the area of biomedical, physical, and technology sciences.

As established by the survey, the unemployed youth were most encouraged to design their careers by such personal characteristics as proactiveness, responsibility, and communicability. Mobility, independence, and creativity were found to be less important for the survey participants.

For the unemployed educated youth, the most important abilities that encouraged career designing included the ability to set and implement career goals, to rela- 
te their hobbies to professional interests, to compete in the labour market, to think strategically, to reflect on their vocation, and to take career-related decisions. The women more frequently than the men tended to think that career designing was promoted by the ability to reflect on the inner vocation, to plan and manage one's personal career, and to take career-related decisions. The senior survey participants (aged 25 to 29) more than the junior ones (aged 21 to 24) tended to think that career designing was promoted by the reflection on their vocation, the ability of strategic thinking, and the ability to relate one's hobbies to professional interests. Young unemployed people with higher education were found to be ambitious, proactive, ready to take risks and to learn, motivated for career design, receptive to innovation, able to use modern technologies, and looking for ways of presenting themselves to employers.

In the opinion of the survey participants, the most important external factors that affected career design included the general national economic situation, the acquired education, and the opportunity of lifelong learning. Another two factors were innovations and novelties in the professional field and parents' financial situation.

For the unemployed educated youth, major obstacles in career designing were the lack of practical professional knowledge and skills, improperly trained qualities required for the chosen profession, and the overestimation of one's strength and potential. The women more frequently than the men believed that career designing was impeded by the overestimation of one's strength and potential. Another major obstacle was non-compliance of the labour market demands with the acquired specialisation and the ignorance of the labour market trends.

The unemployed educated young people estimated their career designing competence as strong and grounded the argument on the fact that they possessed social skills (the ability to make a contact, to maintain a conversation, to discuss, etc.), morover, they had created good resumes. They understood that individuals with a developed career designing competence found it easier to take decisions at any stage of their careers, to choose a good alternative solution in difficulty, and to adapt to economic changes.

The senior survey participants were found to lower estimate their ability to clearly identify their personal strengths and weaknesses, as well as the knowledge of the labour market trends. However, the senior survey participants (aged 25 to 29) were more concerned about their career development plans than the junior ones (aged 21 to 24). The young unemployed youth with higher academic degrees in their career design were better able to identify their personal strengths and weaknesses and less seldom made their career development plans. Thus, the holders of the bachelor and master's degrees believed they better knew themselves and were 
better able to identify their personal strengths and weaknesses than those whith non-university education.

The hypothesis of the survey was confirmed. Young unemployed people with higher education were encouraged to design their careers by the constantly changing economic situation, the social status, and the opportunities of lifelong learning. The career design of educated youth was affected by such personal qualities as responsibility, proactiveness, inquisitiveness, etc., as well as the abilities to plan and manage their careers and to take career-related decisions. The career designing of young unemployed people with higher education was impeded by the absence of qualities required by the chosen profession, the overestimation of their own strength and potential, the absence of practical professional knowledge and skills, and the ignorance of the labour market trends. 